Conclusions. The testing of methodology showed that the proposed composition of a series of maps provides a fairly complete solar and wind energy resource assessment at the regional level. Joint analysis of natural and technical potential maps helps to evaluate the prospects using different types of power plants on renewable energy, to make a comparative analysis of winds at different altitudes and solar radiation values, coming to the surface from different angles of inclination and orientation, to define the predicted production of heat and electricity. It is specially important to use all available data sources and make their comparison.

Maps of factors and constraints that affect the placement of objects on renewable energy allow to define territories, the most promising for allocation of solar and wind energy. At the same time production of individual maps showing the group of factors make it possible to clarify what type of restriction is present on a particular site, that can facilitate the search for information materials and analysis on a larger scale during the development process. Factors and constraints maps unit may vary depending on the nature, features and climate of the region. But the overall logic of their thematic content set forth in the procedure does not change.

Maps of promising areas are the main result of the evaluation. They marked the sites that are completely unsuitable for placing objects on renewable energy and sites with a low degree of suitability. About $50 \%$ of the Volgograd region territory marked with a high degree of suitability by the natural and environmental factors, as well as socio-economic background to the development of renewable energy.

The whole series of maps in general allows to evaluate the resource potential of solar and wind energy at the regional level with a sufficient resolution for this scale and reliability. Map series is an information basis for solving a variety of tasks on a regional scale.

УДК 502, 504, 574

T.S. Nokelaynen ${ }^{1}$

\title{
MAPPING OF THE ENVIRONMENTAL IMPACTS OF RAILWAY TRANSPORT IN RUSSIA
}

\begin{abstract}
Nowadays more and more attention is paid to climate change policy and sustainable development, for which transport still presents a major challenge. Railway transport plays an important role in the pollution of the natural environment. Therefore, it is highly important to monitor and analyse the environmental impacts of railway transport at the county scale. For this purpose, the thematic ecological database was developed for the territory of Russia and the digital map of the environmental impacts of railway transport was created at a scale of 1:20 000 000. The map is representing linear pollution connected with railway transportation systems, which is accessed according to the traffic intensity and types of freight transported on the routes. The major criteria of evaluation are freight volumes, the presence of polluting cargos and passenger train frequency. Conducted research aims to support decision makers with comprehensive data on the environmental impact of railway transport and helps to define the priority regions of Russia requiring measures of improvement of transport and ecological conditions.
\end{abstract}

Key words: Railway Transport, Environment, Pollution, Ecological Mapping.

Introduction. Railway transport is historically the main form of arterial transport in Russia. The railway network distribution on the territory of Russia has developed very unevenly. This is due not only to the vast territory of the country, but also to a large territorial differentiation in its population, as

${ }^{1}$ M.V. Lomonosov Moscow State University, Faculty of Geography, World Data Center for Geography, Moscow, 119991, Russia; e-mail: nokelta@geogr.msu.su. 
well as in the level and type of economic development. Railways are among the main elements of the country's landscape territorial framework and serve as the main provider of interstate freight and passenger transportation [Nokelaynen, 2009]. More than 40\% of total freight and 30\% of passenger traffic is carried by rail. The structure of railway transported goods in Russia is dominated by commodity cargoes (coal, oil derivatives, ores and construction materials) [Transport..., 2014].

The main types of environmental impacts caused by railway transport are related to the emissions of chemical substances in forms of solids, liquids and gases entering all components of the environment [Wilkomirski et al., 2011]. Atmospheric emissions from the rail industry contain solids of organic and inorganic origin: dust and soot $-50 \%$; carbon monoxide (CO) $-23 \%$; sulfur dioxide (SO2) - 22\%; nitrogen dioxide (NO2) - 3\%. Other substances (acid and alkali vapors, fluorine compounds, hydrocarbons, hydrogen sulfide, acetone, gasoline vapors, and ammonia) make up the rest $2 \%$ [Gosudarstvennyj..., 2014]. In the last decades the level of atmospheric pollution associated with railway transport has significantly declined due to structural changes in the locomotive fleet caused by the introduction of electric locomotives.

Soil pollution occurs mainly due to fuel transfer and transportation of bulk cargoes using open rail cars. For example, the rate of oil loss during tank transportation equals to $0,339-0,381 \mathrm{~kg}$ per 1 ton of cargo (depending on the season and regional climate) [Roshydromet, 2014]. According to the Interdepartmental Commission on Environmental Safety of the Russian Security Council, about 30\% of railway accidents are related to oil spills. At the same time, oil cargo (crude oil, diesel and fuel) accounts for the major part of hazardous materials transported by rail. Apart from that, railway areas are subject to polycyclic aromatic hydrocarbons (PAHs) and heavy metal emissions, which are highly toxic and tend to accumulate in the environment [Liu et al. 2009]. Presence of PAHs pollution is mainly caused by machine grease and fuel oils used for rolling stock exploitation, and by creosote, used for railway ties [Thierfelder and Sandström, 2008]. Passenger transport is producing excessive amounts of waste, for example, a single passenger car yearly dilutes up to $200 \mathrm{~m}^{3}$ of wastewater and produces about 12 tons of solid waste per passenger-kilometer [Gosudarstvennyj..., 2014]. Transportation of explosives, chemicals and other hazardous materials by rail can also pose an environmental threat.

Noise and vibration are one of the key concerns related to railways in residential areas which recently started to receive more attention [Brons et al., 2003; Peris et al., 2016]. The noise pollution associated with the railway operation reaches an average of $68-87 \mathrm{~dB}$ at a distance of $25 \mathrm{~m}$ from the center of the railroad track [Ivanov et al., 2012]. The other adverse effects are related to alienation of territories and consumption of water, fuel and energy induced by the railway infrastructure. Railways are constructed on the animal migration routes disturbing natural communities, causing loss of habitats and affecting species and ecosystems [Karlson et al., 2016].

Taking into account all the adverse environmental effects imposed by railway transport, it can be noted that it is still more environmentally friendly than road transport [Nokelaynen, 2015]. Travelling by rail is on average 3 to 10 times less CO2 intensive compared with road or air transport and land use per passenger-km for rail is about 3.5 times lower than for cars [Rail..., 2015].

In order to study a number of problems which exist in the railway industry, spatial analysis and an integrated cartographic assessment of the current traffic situation is required. A series of thematic maps created using GIS technologies can be used to demonstrate the state of the transportation system, its interrelationship with the socio-economic development of the country, as well as its environmental impacts. A similar approach has been already implemented in a series of thematic maps devoted to the environmental impacts of different types of transport, such as road transport [Samojlenko and Nokelaynen, 2002], inland waterway transport [Maslennikova et al, 2002] and pipeline transport [Gennadiev et al, 2002], developed as a part of the Environmental Atlas of Russia. The aim of this study is to summarize the previous expertise on mapping of the environmental impacts of transport and produce an up-to-date geodatabase and map of the influence of railways on the environment in Russia.

Materials and methods. Atlas information system on the sustainable development of Russia, created at the Faculty of Geography of the Lomonosov Moscow State University, contains a variety of 
resources for simulation, visualization and integrated analysis of information on natural, economic and socio-demographic sustainability across the regions of Russia. All the components of the system are analyzed considering their dynamic behavior and Russia is seen as an integral part of a global system [Tikunov et al., 2007]. The transport section of the system includes an extensive spatiotemporal database developed according to the existing standards of geodatabase design [Butler, 2008].

Geodatabase on the railway transport of Russia consists of the following information blocks [Nokelaynen and Belousov, 2010]:

- The Retrospective block, including historical information on the development, growth and electrification of the Russian railway network.

- The Environmental block, including information on the anthropogenic effects imposed by railway transport and the risk of natural hazards along the railways.

- The Socio-economic block, including information on the railway technical equipment, public accessibility, service performance and passenger transportation tariffs.

- The Perspective block, including information on the existing and future railway development projects (lines under construction, planned high-speed rail, etc.).

The developed geodatabase was already used for thematic mapping of railway transport implemented with the contribution of the author in a number of federal projects, such as:

- Environmental Atlas of Russia;

- Atlas of natural and technological hazards of the Russian Federation;

- National Atlas of Russia;

- Atlas of socio-economic development of Russia;

- The cartographic animation «The development of Russian railway network».

In addition to the materials obtained from the Atlas information system on the sustainable development of Russia, other sources of data were analyzed, such as the official statistics from the Russian Federal State Statistics Service [Ohrana..., 2013] and the materials from the official site of JSC «Russian Railways» [Godovye..., 2015].

The use of GIS technologies allowed mapping of the environmental impacts of railway transport in Russia, which was conducted in ArcGIS environment according to the following steps:

1. Updating the geodatabase on the modern railway network of Russia (adding recently constructed or electrified railway sections).

2. Creating a series of thematic layers on railway operations (freight and passenger traffic, train frequency, etc.).

3. Creating a series of thematic layers on railway ecology (transportation of chemicals and hazardous materials, oil loading and offloading points, etc.).

4. Creating a series of thematic layers on railway nodes (freight and passenger turnover, connection with nearby airports, seaports and river ports, etc.).

5. Developing a methodology for assessment of pollution along railways.

6. Developing a methodology for estimation of transport pollution in cities.

7. Composing a thematic map of environmental impacts of railway transport in Russia.

Results and discussion. The main outcome of the research is the creation of the map «Environmental Impacts of Railway Transport in Russia» at the scale of 1:20 000 000, where the negative environmental effects caused by railway transport are characterized by the degree of pollution along the railways (Fig. 1). The main evaluation criteria selected for the railway classification are freight and passenger traffic, train frequency and transportation of hazardous materials on the routes.

All the railways are grouped into three categories according to the degree of environmental pollution (high, moderate and low). The high level of pollution is assigned to the mainline railways which are characterized by annual freight volume of more than 30 million tons in both directions, over 20 pairs of passenger trains running daily and the zone of environmental influence stretching up to $300 \mathrm{~m}$. The moderate level of pollution is found along the railways with annual freight volume in the range of 10-30 million tons and about 10 to 20 pairs of passenger trains running daily. This category also includes roads with annual freight volume less than 10 million tons, which are used for 
transporting bulk cargos polluting the environment, such as coal and lignite, metallic and non-metallic ores, crude oil and oil derivatives and construction materials. The low level of pollution is associated with the railways with annual freight volume less than 10 million tons and less than 10 pairs of passenger trains running daily, which are transporting negligible amounts of polluting cargos.

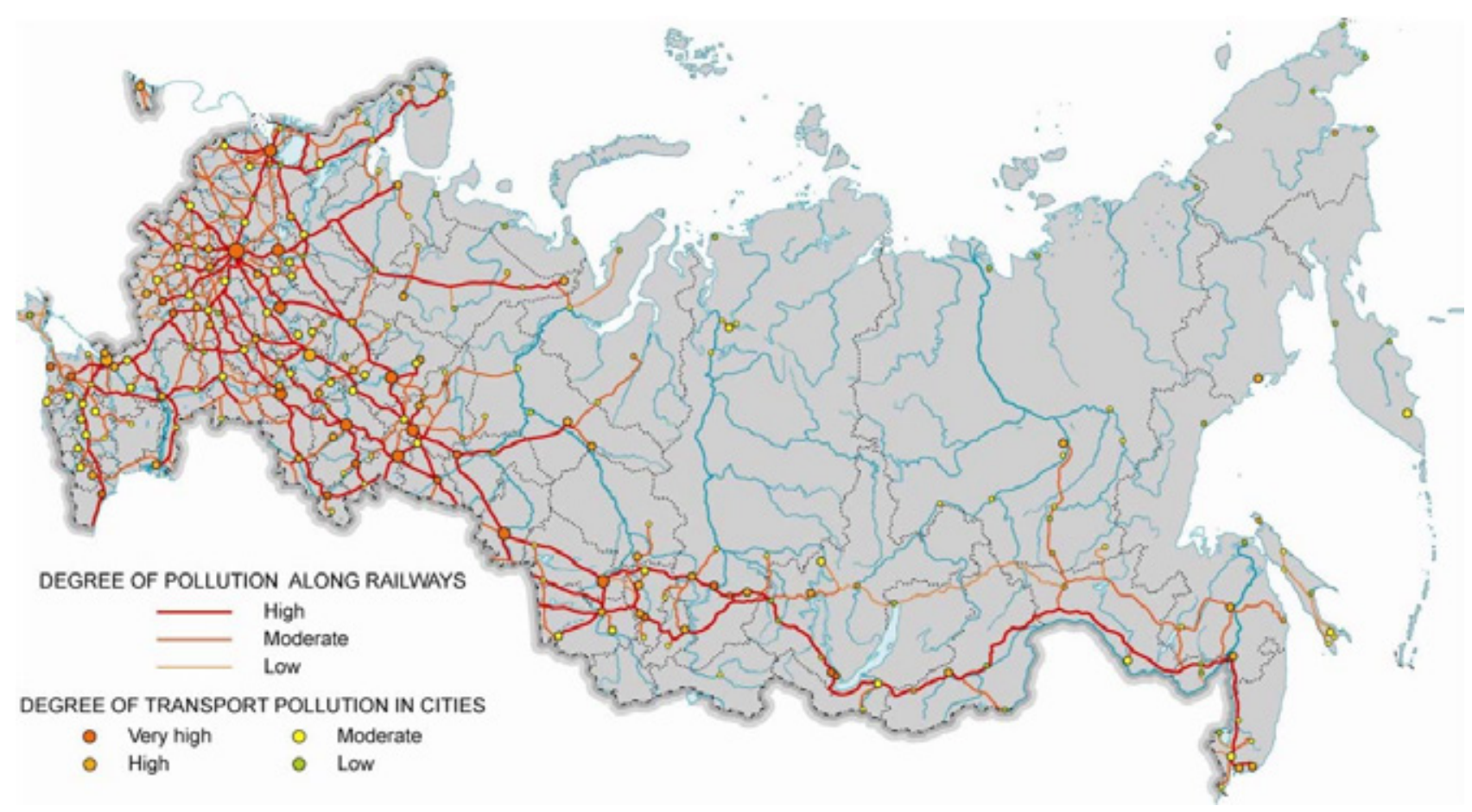

Fig. 1. Environmental Impacts of Railway Transport in Russia

Urban transport pollution is estimated by using a series of indirect indicators providing information on the railway traffic structure and volume of freight turnover within the cities. The results are shown on the map with point symbols varying in size and color. The size of the symbol is representing the total population of a city and the color is reflecting the degree of railway transport pollution (very high, high, moderate or low). The very high degree of pollution refers to the largest railway nodes with the annual freight turnover of more than 20 million tonnes, such as Moscow, St. Petersburg, Samara, Novosibirsk, Ufa, Chelyabinsk, etc. This category also includes railway junctions and sea (river) ports with a smaller level of freight turnover, but with a large share of polluting cargoes, for example, Magnitogorsk, Novorossiysk, Makhachkala and Orsk. The high degree of pollution is assigned to major Russian cities with the annual freight turnover varying from 5 to 20 million tonnes, such as Rostov-on-Don, Kazan, Tula, Astrakhan, Chita, Khabarovsk, etc. Railway nodes with the annual freight turnover between 1 and 5 million tons with a significant share of polluting cargoes are characterized by the moderate level of pollution (Kursk, Smolensk, Pskov, Saratov, Ulan-Ude, etc.). The low degree of pollution is attributed to all the rest railway transportation and distribution nodes with the annual freight turnover less than 1 million tons, which are predominantly found on the poorly developed territories.

The largest percent of all cargoes is delivered to seaports by rail. The seaport symbols are included into the map contents, where symbol size is representing the freight turnover (more than $100 ; 50-75 ; 10-25 ; 1-10$; less than 1 million tons per year). In addition to that, oil loading and offloading points are shown using special symbols, since they are associated with greater risks for the environment.

Conclusion. The construction and operation of railways are causing substantial negative impacts on the natural environment, associated with atmospheric emissions, soil contamination, land degradation and habitat loss. The conducted research enabled to define the key regions of Russia 
which are subject to a significant anthropogenic load associated with the railway transport and which require adoption of new environmentally-oriented policies and industry standards. The map «Environmental Impacts of Railway Transport in Russia» which was produced as a part of this study helped to assess the degree of pollution along the railways and in major cities of Russia. The approach that was used shows that the creation of thematic maps using GIS technology and multilayer analysis can be used for an assessment of railway transport pollution, and can serve as an essential part of a decision support system in order to facilitate:

- Local and regional railway environmental impact and safety assessment.

- Design and construction of new railway lines.

- Environmentally oriented railway infrastructure development projects.

- Nature protection initiatives in the railway sector.

All the information involved in this study was gathered and stored in a format of an ArcGIS geodatabase, which makes the database dynamic and easy to edit and allows updating the attribute information, conducting additional multi-layer analysis and creating new maps.

\section{REFERENCES}

1. Brons M., Nijkamp P., Pels E., Rietveld P. (2003). Railroad noise: economic valuation and policy. Transportation Research Part D: Transport and Environment, 8(3), Pp. 169-184.

2. Butler J.A. (2008). Designing geodatabases for transportation. Redlands, Calif.: ESRI Press, $461 \mathrm{p}$.

3. Gennadiev A.N., Golovanov D.N., Nokelaynen T.S., Pikovskij J.I., Tal'skaja N.N. (2002). Opasnost' vozdejstvija nefteprovodnogo transporta. [Environmental risks of oil pipelines]. Environmental Atlas of Russia. ZAO «Karta», Pp. 30-31. (In Russian).

4. Godovye otchety OAO «RZhD» za 2008-2015 gg. [Annual reports of JSC «Russian Railways» for the 2008-2015]. (2015). (www.rzd.ru). (In Russian).

5. Gosudarstvennyj doklad «O sostojanii i ob ohrane okruzhajushhej sredy Rossijskoj Federacii v 2013 godu». [State Report: On the state and Environmental Protection of the Russian Federation in 2013]. (2014). Moscow, 463 p. (In Russian).

6. Ivanov N.I., Kuklin D.A., Matveev P.V., Butorina M.V. (2012). Snizhenie shuma zheleznodorozhnogo transporta. [Noise reduction for rail transport]. Bezopasnost' zhiznedejatel'nosti, 12 (144), Pp. 2-24. (In Russian).

7. Karlson M., Karlsson C.S.J., Mörtberg U., Olofsson B., Balfors B. (2016). Design and evaluation of railway corridors based on spatial ecological and geological criteria. Transportation Research Part D: Transport and Environment, 46, Pp. 207-228.

8. Liu H., Chen L.P., Ai Y.W., Yang X., Yu Y.H., Zuo Y.B. (2009). Heavy metal contamination in soil alongside mountain railway in Sichuan, China. Environmental Monitoring and Assessment, 152, Pp. 25-33.

9. Maslennikova V.V., Nokelaynen T.S., Samojlenko Z.V., Skornjakov V.A. (2002). Vozdejstvie zheleznodorozhnogo i vodnogo transporta. [Railway and inland water transport impact on the environment]. Environmental Atlas of Russia. ZAO «Karta», Pp. 34-35. (In Russian).

10. Nokelaynen T.S. (2015). GIS-Mapping of the Environmental Impacts of Road Transport in Russia. In: Proceedings of the International Conference InterCarto/InterGis 21 «Sustainable Development of Territories: GIS Theory and Practice»-Krasnodar, Sochi, Suva (Fiji), Pp. 97-100.

11. Nokelaynen T.S. (2009). Perevozki gruzov i passazhirov zheleznodorozhnym transportom. [Rail transport of goods and passengers]. Atlas of socio-economic development of Russia. Moscow, Pp. 136-137. (In Russian).

12. Nokelaynen T.S., Belousov S.K. (2010). GIS-kartografirovanie razvitija zheleznodorozhnogo transporta Rossii. [GIS-Mapping of the Railway Transport Development in Russia]. In: Proceedings of the International Conference InterCarto/InterGis 16 «Sustainable Development of Territories: GIS Theory and Practice». Rostov-on-Don (Russia), Salzburg (Austria), Pp. 25-30. (In Russian). 
13. Roshydromet. (2014). Obzory sostojanija i zagrjaznenija okruzhajushhej sredy v Rossijskoj Federacii za 2007-2014 gody. [Review of the State of the Environment and Environmental Pollution in the Russian Federation: 2007-2014], (www.meteorf.ru). (In Russian).

14. Ohrana okruzhajushhej sredy v Rossii. [Environmental protection in Russia: Statistical book]. (2013). Rosstat, Moscow, 303 p. (In Russian).

15. Peris E., Woodcock J., Sica G., Sharp C., Moorhouse A. T., Waddington D.C. (2016). Guidance for new policy developments on railway noise and vibration. Transportation Research Part A: Policy and Practice, 85, Pp. 76-88.

16. Rail Transport and Environment: Facts and Figures. (2015). The Community of European Railway and Infrastructure Companies (CER). (www.cer.be).

17. Samojlenko Z.V., Nokelaynen T.S. (2002). Vozdejstvie avtomobil'nogo transporta. [Road transport impact on the environment]. Environmental Atlas of Russia. ZAO «Karta», Pp. 36-37. (In Russian).

18. Thierfelder T., Sandström E. (2008). The creosote content of used railway crossties as compared with European stipulations for hazardous waste. The Science of the Total Environment, 402, 106-112.

19. Tikunov V.S., Rubanov I.N., Nokelaynen T.S. (2007). Atlas information system for the sustainable development of territories. In the Proceedings of the XXIII International Cartographic Conference, Moscow, Pp. 123-124.

20. Transport i svjaz' v Rossii: Stat. cb. [Transport and communication in Russia: Statistical book]. (2014). Rosstat, Moscow, 114 p. (In Russian).

21. Witkomirski B., Sudnik-Wójcikowska B., Galera H., Wierzbicka M., Malawska M. (2011). Railway transportation as a serious source of organic and inorganic pollution. Water, Air, and Soil Pollution, 218 (1-4), Pp. 333-345.

\section{Е.А. Прохорова ${ }^{1}$, А.В. Морозова ${ }^{2}$, В.Н. Семин ${ }^{3}$, Я.О. Казарин ${ }^{4}$}

\section{АНАЛИЗ И КАРТОГРАФИРОВАНИЕ ДИНАМИКИ ЧИСЛЕННОСТИ НАСЕЛЕНИЯ ПОЛУОСТРОВА КРЫМ}

Резюме. Изменение государственной принадлежности Крымского полуострова, которое произошло в 2014 году, не могло оставить в стороне проблему анализа и картографирования трансформаций, которые происходят в социально-экономическом укладе округа. В статье рассмотрены способы картографирования динамики численности населения, в частности, в связи с очередным ростом внимания к неравномерности развития социальной инфраструктуры и с возможностями оченки рекреационной нагрузки на территорию. Создана серия карт, которая может способствовать определению тенденций в дальнейшем формировании расселения Крымского федерального округа.

Ключевье слова: картографирование населения, динамика численности населения, расселение Крыма, информачионные ресурсы.

\footnotetext{
${ }^{1}$ Московский государственный университет имени М.В. Ломоносов, географический факультет, кафедра картографии и геоинформатики, Москва, Россия; e-mail: eaprohorova@mail.ru.

${ }^{2}$ Московский государственный университет имени М.В. Ломоносов, географический факультет, кафедра картографии и геоинформатики, Москва, Россия; e-mail: aleksandra.v.morozova@yandex.ru.

${ }_{3}^{3}$ Московский государственный университет имени М.В. Ломоносов, географический факультет, кафедра картографии и геоинформатики, Москва, Россия; e-mail: yanis97@mail.ru.

${ }_{4}^{4}$ Московский государственный университет имени М.В. Ломоносов, географический факультет, кафедра картографии и геоинформатики, Москва, Россия; e-mail: vnsemin@mail.ru.
} 